(C) The Author(s), 2021. Published by Cambridge University Press on behalf of The Hegel Society of Great Britain. This is an Open Access article, distributed under the terms of the Creative Commons Attribution licence (http:/ / creativecommons.org/licenses/by/4.0/), which permits unrestricted re-use, distribution, and reproduction in any medium, provided the original work is properly cited.

\title{
Hegel's Later Theory of Cognition: An Additive or Transformative Model?
}

\author{
Luca Corti
}

\begin{abstract}
This article investigates Hegel's later theory of perception and cognition, identifying and analysing its general assumptions about the relation among the mind's activities. These often unremarked upon assumptions, I claim, continue to underwrite recent interpretive controversies. I demonstrate how a correct understanding of such assumptions points us toward an alternative interpretation of Hegel's model of the mind. I argue that this new model changes how we understand (a) Hegel's later notion of 'non-conceptual content' and (b) his distinction between human and animal minds - two areas that constitute the fault line dividing interpretations of late Hegel. To isolate the relevant assumptions, I use Matthew Boyle's influential conceptual distinction between 'additive' and 'transformative' models of rationality. I demonstrate that Hegel himself addresses the basic issues characterizing this distinction and clarify how approaching his work in these terms presents considerable interpretative and conceptual advantages, including allowing us to defend the position that Hegel adopts a 'transformative' framework of mind. To support this argument, this paper closely analyses Hegel's treatment of sensation (Empfindung), which has not yet been systematically addressed by scholars. I show how sensation can be best understood as part of Hegel's later 'transformative' framework for cognition. I also show how this framework can be extended to other parts of Hegel's theory.
\end{abstract}

\section{Introduction}

Until recently, discussion of Hegel's theoretical position on mind and cognition had been limited mostly to the thoughts outlined in his early writings and the Phenomenology, while his later ideas have remained largely off the radar. ${ }^{1}$ The past few years, however, have seen a growing appreciation of Hegel's later views on these topics. ${ }^{2}$ Within this context, several controversies have arisen regarding how to interpret both the structure of Hegel's argument as well as its core claims. 


\section{Luca Corti}

In this article, I will investigate Hegel's texts with the aim of making order of this controversy by systematizing the conceptual space for possible interpretations. Doing so will allow me to illuminate and defend an approach to Hegel's work that is underexplored in this scholarly context. I will argue that such a particular approach to the text is able to solve several of the typical interpretative and argumentative difficulties affecting standard readings of Hegel's later thought.

In what follows, I will isolate some basic assumptions shared by many current approaches to Hegel. These assumptions, I claim, are the origin point of several recent debates regarding Hegel's later views on cognition. In particular, they affect two controversies surrounding his response to two sets of questions about the nature of perceptual experience and the difference between animal and human cognition. The first controversy revolves around Hegel's account of nonconceptual content: in his view, to what extent are conceptual capacities involved in perception? Do humans enjoy non-conceptual intentional representations? The second controversy concerns Hegel's account of the difference between animal and human cognition: do humans share some common perceptual states and cognitive components with animals or not? Is there a categorial or 'hard-line' difference between human and animal cognition?

Hegel has featured prominently in debates on both non-conceptual content and the hard-line/low-line question. ${ }^{3}$ His mature stance, however, is far from clear. On the one hand, he has been considered the champion of conceptualism, or sometimes even of super-conceptualism. Inhabiting this role, he has inspired a number of renowned contemporary philosophers. ${ }^{4}$ On the other hand, this standard image of Hegel has been challenged by various scholars who argue that his system instead advances a theory in opposition to the one normally attributed to him by conceptualists: such scholars read his late work as non-conceptualist and as defending a continuity between animal and human mental life rooted in some basic shared cognitive powers or activities. ${ }^{5}$

In what follows, I will show that addressing this divide between the two largely different 'Hegels' requires taking a few steps backward to consider the broader assumptions underlying Hegel's understanding of cognition and his philosophical procedure. Such assumptions lie at the heart of the divergences among interpretations of Hegel's ideas regarding single cognitive activities. I will argue that a fruitful way to isolate these assumptions is to deploy a distinction identified by Matt Boyle, who has recently proposed two general models of the mind: those that are 'additive' and those that are 'transformative' (Boyle 2016). This taxonomy aims to organize theories of the mind emerging from both classical and contemporary traditions; in recent years, it has been especially useful for opening up space for new interpretations of Kant (see Kern and Kietzmann 2017; Conant 2017; Boyle 2005). 


\section{Hegel's Later Theory of Cognition}

My contention is that Boyle's conceptual framework is helpful for clarifying Hegel's later views on cognition and the controversies surrounding them, since it enables us to make visible decisive distinctions that Hegel himself highlighted and to defend a coherent interpretation of his thought. Drawing on Boyle, I will show that the fault line dividing the various approaches to Hegel's later views does not primarily emerge from the question of the anatomy of the lower human mental faculties and their proximity to or distance from animal beings. Rather, it derives from the question of the separability (Trennung) of the mind's faculties, which, as I will show, is a concern that underlies Hegel's reflections and shapes his argument. Indeed, I will contend that any discussion of Hegel's later theory-including his stance on conceptualism or animal-cognition-must first answer a more fundamental question: does Hegel uphold an 'additive' or a 'transformative' theory of the mind and rationality? This question conceptually illuminates the general structure of Hegel's later theory as well as interpretative controversies about it.

In addition to showing that the question of 'separability' is fundamental to understanding both Hegel's theory and its interpretations, I will argue that Hegel is best read as making a strong claim about the inseparability of the mind's activities - a position that I will show is present in his later texts and which profoundly shapes the method and the structure of his argument in the Philosopby of Spirit. The model of cognition resulting from this thesis of inseparability is best understood as upholding the general outlines of a resolute transformative position. ${ }^{6}$

To unfold my argument, I will proceed as follows: 1) After a brief survey of relevant distinctions between the two models of rationality, I will show how Hegel himself identified these different approaches to the mind as he developed his account and discussed the 'separation' (Trennung) among its activities. 2) I then will show how the standard reading of the Philosophy of Subjective Spirit-which commits Hegel to non-conceptualism and the low-line theory on animal cognitiondepends on a deep underlying commitment to an 'additive' model of the mind. 3) Next I will provide both arguments and textual evidence to show that Hegel largely rejects this 'additive' model and the assumptions upon which it rests. 4) Finally, I will propose a shift of perspective by offering evidence for an alternative Hegelian account of the mind that shares essential insights with what Boyle calls a 'transformative' model. This less-explored approach to Hegel's later thought on cognition opens up a promising new way of understanding his texts that solves many interpretative difficulties. To make my case, I will focus on Hegel's Anthropology and in particular on his account of sensation. Systematic study of the notion of sensation in Hegel's thought is still lacking; analysing this notion (a supposedly paradigmatic example of non-conceptual content) will enable me to both expand the existing literature and show how Hegel's views are best understood as part of a transformative model of mind. Yet, as I hope will become clear, this interpretative approach can also be extended to the other parts of Hegel's theory of cognition. 


\section{Luca Corti}

\section{Additive vs. transformative models of rationality}

According to Boyle's influential distinction, 'additive conceptions' portray the mind as composed of different levels that are distinct from one another and operate independently. Some of those levels — traditionally the 'lower' ones-are usually considered to be shared with non-rational animals. Distinctively rational capacities 'add on' to these lower levels as additional and independent higher ones. As a result, rational human beings are understood to share with non-rational animals the capacity to cognitively interact with the environment through perception and desire, but as rational beings, they are also understood to possess something in addition to these capacities: namely, distinctive rational conceptual abilities. ${ }^{7}$

Boyle is clear that both the rational and non-rational levels of the mind can be specified in different ways (in terms of capacities, powers, modules, faculties, informational systems, etc.). Regardless of how they are identified, however, rational capacities are always conceived of as a particular element or level in our cognitive architecture, which accumulates on top of lower ones without altering their nature. To use another well-known metaphor, this model portrays the mind as a layercake': rationality is just an additional 'layer' resting atop the others already constituting our mental equipment (Conant 2017).

Against this view, the 'transformative theorist' argues that having conceptual capacities - those faculties that enable us to make judgments and assess things in terms of concepts - affects our supposedly 'lower' capacities to perceive and have representational states and desires by conferring them with a new, different form. To put it in Boyle's terms: 'our rationality does make a basic difference to the nature of our perceiving: it gives us a 'special form' of perceptual sensitivity to our environment, one whose operations are themselves informed by our capacity to weigh reasons' (Boyle 2016: 4). In this framework, the presence of rationality 'permeates', to use McDowell's famous metaphor, and transforms the entire anatomy of our mind, reshaping our cognitive powers in a way that sets them apart-in a categorical sense-from non-rational ones (cf. McDowell 2009: 272). According to this perspective, 'rational perceiving' and 'rational desiring' are different in kind from non-rational perception or desire, and animal cognitive life is thus essentially different from human cognitive life.

Boyle's distinction is framed carefully, and it aspires to capture a wide set of positions, both contemporary and historical, especially in relation to Kant. ${ }^{8}$ As a tool for philosophical reflection, Boyle's distinction flags many problems that might not otherwise be visible. This is especially the case, I argue, for Hegel's later theory of cognition, since Hegel himself makes a distinction similar to Boyle's. To see this clearly, it is worth at least initially remaining at an abstract level, without committing Hegel to any particular view about single cognitive 
faculties, and focusing solely on his stance on the notion key to Boyle's distinction: 'separability'. ' For Boyle, 'separability' is the main issue setting apart the two models: whereas the additive theorist defends strong distinctions among discrete activities (or capacities, modules or faculties), arguing that 'rationality' does not affect the nature of other activities of the mind (which therefore exist separately or in isolation from rational capacities), the transformative theorist rejects the notion of separability, arguing for the integration of the different activities and the impossibility of 'separating' them from each other without altering their nature. ${ }^{10}$

Understood in this sense, 'separability' is also a central notion in Hegel's later theory of mind and cognition. Therefore, before turning to the single activities making up Hegel's theory of mind (sensation, feeling, intuition, language, etc.), it is important to take note of Hegel's stance on the role and weight of 'separability' in his general account of the mind's faculties. In Hegelian terms, this stance relates directly to the problem of Trennung, which lays the groundwork for Hegel's late theory of cognition described in the Philosophy of Subjective Spirit. As I will show, divergences in how this part of Hegel's theory gets interpreted stem in large part from different ways of reading the issue of 'separability'.

\section{Hegel and the separability of the mind's activities: Philosophy of Subjective Spirit}

The problem of Trennung appears throughout Hegel's writings. Hegel refers to it every time he addresses cognitive or spiritual activities in either the Encyclopedia or his Lectures. The issue is also particularly visible in the first section of the Anthropology. Located at the very beginning of the Pbilosophy of Spirit, the Anthropology is (to say the least) a very controversial text. It is here that Hegel deals with 'spirit, observed first in its purely natural being, and in its immediate union with the organic body, as well as in its dependency on the body's affections and states'. ${ }^{11}$ Notably, the text explores basic forms of cognition related to bodily effects that appear in some sense 'natural'-so natural, in fact, that some are also discussed in the Philosophy of Nature. Hegel also explores elements of perception that do not seem to be mediated by concepts. Although perhaps one of the most neglected parts of Hegel's system in the last century, the Anthropology is crucial for understanding Hegel's views on cognition, including the relation between animal and human cognition, as well as his stance on conceptualism with regard to perception. $^{12}$

In this context, the question of 'separability' takes the following forms: how does Hegel conceive of basic 'spiritual' activities that are cognitively related to the body? Do they constitute a layer in our mental anatomy that is shared with animals? Do they provide independent, non-conceptual components to perception? 


\section{Luca Corti}

As we will see, most scholars tend to see Hegel as answering 'yes' to the latter two questions. Indeed, Hegel is most often assigned to what Boyle calls the 'additive theorist' group and read as embracing non-conceptualism on the issue of perception and advancing a low-line theory on the issue of animal experience and cognition. In what follows, I will outline how readers come to this interpretation and upon which assumptions and textual evidence it is based. I then will further clarify how this reading considers the specific case of Hegel's treatment of sensation, which will serve as a foil highlighting the key problems related to this approach.

\section{II.i. The standard reading: Anthropology as addressing a lower layer of cognition}

Most scholars implicitly or explicitly tend to read Hegel's treatment of the soul as his account of an autonomous, 'separable' layer of human cognitive life. In this perspective, the soul refers to a stock of activities constituting the bottom level of our mental architecture. According to this additive reading, the various levels of the mind are understood to be robustly independent: they can be separated from 'higher' ones without any alteration of functions; accordingly, they also can sometimes operate separately. Some textual evidence seems to point in this direction. Hegel himself speaks of 'the becoming independent [selbständigwerden] of the sentient soul, [its] separation [Trennung] from mediated, understanding consciousness' (PSS: \$406A, translation modified). ${ }^{13}$ This basic, almost natural level of our cognition, which includes several activities (Tätigkeiten), can be qualified in many different ways. Two main lines of interpretation can be identified in the scholarly literature.

First, many readers - often under the influence of psychoanalytic theoryhave been intrigued by the fact that Hegel seems to describe soul as a system of powers operating beneath consciousness and rationality, i.e., as an 'unconscious' domain into which we can plunge when the higher faculties linked to consciousness and rationality are absent (or malfunction). There has been a widespread tendency to read Hegel's notion of soul as a more or less refined theory of the unconscious (see for instance Mills 2000, 2002; Berthold-Bond 1995; Severino 1983; Christensen 1968). Hegel in fact claims that, in some cases, 'the subject seems to sink into a dark, contentless, self-feeling, without proceeding to activating consciousness; he has no connection with the external world' ( $G W: 25: 2: 709)$. Hegel also describes losing rationality as 'falling back into the level of the feeling soul' (LPS: 89; PSS: \$408).

According to a second line of interpretation, however, more influenced by the philosophy of perception, these same paragraphs in the Anthropology refer to a fundamental cognitive 'layer' that makes an autonomous contribution to perception in the form of non-conceptual representations. These representations are understood to be the basic building blocks of our mental life. One of the basic capacities making up this bottom-level of cognition is sensing (empfinden), which is linked with episodes called 'sensations': 'Sensation is this primary shape, within which the soul is first 


\section{Hegel's Later Theory of Cognition}

properly the soul in that it is a concrete individuality' (PSS: I: 125). In the context of 'separability', the activity of sensing is conceived as operating independently of higher activities. This produces a particular kind of mental content in which, in Hegel's words, 'there is no objective consciousness, no knowledge of the world as of something actually posited from out of myself' (PSS: \$402). Sensing therefore has been taken as paradigmatic of how Hegel theorizes independent, 'separable' sets of episodes whose content (independent of their phenomenal or ontological features) is explicitly nonconceptual and, according to many scholars, shared with non-rational animals.

What is important to note is that both the psychologically (or psychoanalytically) oriented reading and this epistemologically oriented one share a common commitment to separability (see for instance Winfield 2007, 2010; Houlgate 2006, 2018; deVries 1988, 2013): both interpretations share the view that a certain set of capacities is independent and can be isolated from higher ones without being altered. To see how this assumption works - and highlight its problems-let me now focus more closely on Hegel's theory of sensation.

\section{II.ii. Sensation and the additive vien}

Hegel's theory of sensation is particularly representative of the problems at stake. Not only is sensation, as Hegel himself writes, 'the first and more immediate form in which something appears’ (PSS: \$400; see also GW: 25:2:804), but the notion has also been taken as Hegel's name for a natural, primitive, non-conceptual content and as the label for the domain of episodes and activities shared with animals. Systematic study of the notion of 'sensation' in Hegel's thought is lacking. Analysing it thus presents the opportunity to both contribute to the literature and identify what potential advantages a transformative interpretation of Hegel might offer over and above the traditional additive one.

\section{II.iii. What is 'sensation' according to Hegel?}

Hegel inherits a long-standing philosophical tradition on 'sensation' that culminates with Kant and post-Kantian thinking (Redding 1999). His analysis of the notion has yet to be carefully reconstructed. Here I will isolate its main features, in order to then explore why it is generally interpreted using an 'additive' model.

Looking carefully at Hegel's text, we see that Hegel identifies many things as 'sensations': he refers to 'warmth' and 'pain', but also to 'shame' and 'pride' as well as to sensations related to ethical matters and beauty (GW: 25:2:655ff.; PSS: \401Z). Hegel's taxonomy distinguishes between two basic kinds of sensations, which he calls 'external sensations' and 'internal sensations' (GW: 25:2:655ff.; GW: 25:1:58ff., 673ff.; PSS: \401). I will focus on sensations of the first typewhich can also be called 'sensory sensations' (sinnliche Empfindung) (EL: \50)- 


\section{Luca Corti}

because these are the sensations involved in perception. Hegel states that their content 'has been taken from nature' (GW: 25:1:58). ${ }^{14}$ The main features of Empfindung as they appear in Hegel's texts are the following: ${ }^{15}$

(1) Empfindung are items in one's mental life towards which one is specifically passive. In most of his works (Encyclopedia, Lectures on the Philosophy of Subjective Spirit, and Fragment on the Philosophy of Spirit), Hegel stresses the etymology of the word 'to sense' (empfinden), noticing that in German it contains the word 'to find' (finden). This pun was first used by Fichte in his Lectures ( $W: 1: 3: 150$ ), and Hegel mobilizes it again: Empfinden, he repeats, is a form of finding something in oneself (in sich etwas finden) (GW: 25:2:648, 655; see also LPS: 111; PSS: I: 106, PSS: SS399-402).

(2) Hegel clearly distinguishes both conceptually and terminologically between the mere physiological side of sensing (as addressed from the point of view of natural science, i.e., Sensibilität) and analysis of sensing as an activity or episode of mind (Empfindung). The latter, he claims, cannot be identified with or merely reduced to the type of physiological discourse treated in the Philosophy of Nature.

(3) Sensation is defined as an element essentially linked to the body. When the soul senses (empfindet), Hegel writes, it is determined immediately, therefore in a natural and bodily manner' (PSS: \403A). Hegel also adds that the body is the 'sphere of sensation, both for internal as well as external sensations' (PSS: $₫ 401 \mathrm{~A}){ }^{16}$

(4) Like Kantian intuitions, Hegelian sensations are singular (PSS: \402, \$402Z). In his Lectures, Hegel states that 'all the sensed [alles Empfundene] has the form of the singularized [Vereinzeltes]' (GW: $25: 2: 10){ }^{17}$

(5) Sensations are introduced as episodes constitutively independent from our conceptual capacities. In Hegel's formulation, sensations belong to a particular form of subjectivity that 'lacks consciousness and understanding' (PSS: $\$ 400$, translation modified). Therefore, the initial definition of Empfindung does not depend on the way we conceive of conceptual capacities-which will appear only later in his argument.

(6) The content of a given sensation is in itself conceptually undetermined, to the extent that, for Hegel, it cannot be said to be 'subjective' or 'objective': this distinction appears to be a result of later activity of the mind. In his Lectures, Hegel claims that 'the forms of subjectivity and objectivity have nothing to do with this' (LPS: 177) and that 'in sensation the distinction between subject and object is not yet present, it belongs first to consciousness' (GW: 25:2:653). 
(7) In the same vein, categorizations of an experience such as 'dream', 'hallucination', or 'reality' are not inherent to the sensation itself. Any sensation can participate in all of these forms of experience (it 'can be also the content of dreams' (LPS: 107)).

(8) Hegel appears to claim that this indeterminacy also applies to a sensation's spatiality and temporality. In Hegel's words, sensed contents in themselves are neither spatial nor temporal: it is the mind's activity (in the form of what Hegel calls intelligence) that first constitutes the contents of sensations as temporal and spatial: 'Intelligence [...] determines the content of sensation as being that is outside itself, casts it out into space and time' (PSS: §448). ${ }^{18}$

(9) Empfindung also seems to lack any constitutive relationship with language. 'Sensing', per se, is not necessarily articulable in a discursive manner. Like feelings, empfindungen are, according to some passages in Hegel, 'ineffable' (das Unsagbare) (EL: \$20).

(10) Given the points above, one could not only say that sensation lacks the kind of intentionality typical of conceptual episodes but also that it does not seem to be intentional at all. As Hegel claims, 'from the point of view of sensation [...] there is no objective consciousness, no knowing of the world as something actually posited outside of myself' (PSS: \$402Z). Sensations do not present us with objects or proto-objects. ${ }^{19}$

(11) Empfindung is an element of our cognitive life that also appears in the Naturphilosophie, where it is attributed to animals (EN: \351Z). This raises the big question — which we will address below-as to whether or not humans share this activity with animals.

\section{The 'additive' interpretation of sensation}

Interpretations of Hegel's later thought must find a way to link these features together into a single coherent view. The way readers starting from an 'additive' position do so is by understanding Hegelian sensation as a basic independent capacity responsible for one's first cognitive engagements with external reality. From this perspective, the non-representational, descriptive features of sensation still need to be qualified. Most importantly, a story must be told about how sensation affects the constitution of objective representations and relates to higher mental capacities. Since Hegel in fact enriches his account of the mind in subsequent sections of his Philosophy of Subjective Sprit, additive theorists need to address how those later passages should be understood. 


\section{Luca Corti}

In this regard, some kinds of approaches can be ruled out. For instance, it has been convincingly argued by many interpreters that Hegel's argument should not be read as offering insight into the 'ontogenesis' of rationality or into rationality's 'phylogenesis'. Although references to both processes are present in the text, and some interpreters still read Hegel in this way, many scholars have identified that Hegel himself explicitly disavows this kind of interpretation of his argument. ${ }^{20}$

A different solution is to take Hegel's treatment of subsequent activities as an account of how the broader overarching cognitive apparatus operates on sensations in order to elaborate content. In this reading, the subsequent components Hegel considers would index cognitive capacities that are just as autonomous as those previously introduced and which relate to and further elaborate the content produced by earlier components, conferring them with new features. This results in a view of cognition as constituted by various forms of cognitive activity exercised upon 'given' sensible material in order to generate new forms of self-relation as well as new kinds of representations. ${ }^{21}$ Hegel seems to support this kind of interpretation, as he often writes as if he were describing different activities adding onto previous ones and, by the same token, adding features to their contents - essentially a compositional model of spirit. ${ }^{22}$ Various scholars espouse versions of this view. ${ }^{23}$

Reading the text in this way, it is not difficult to see Hegel as identifying a lower level of cognition that is separable, independent, and provides non-conceptual sensory contents. This would make Hegel an admittedly peculiar kind of nonconceptualist. $^{24}$ On the other hand, 'additive' interpretations often make reference to the famous passage in which Hegel maintains that 'even animals have soul', adding that 'animals have sensation' (GW: 24:1:158) and 'sensation begins at the animal stage' (GW: 25:1:51; see also GW: 25:1:187, 191). Since Hegel treats 'sensation' and 'soul' not only in the Anthropology but also in the Philosophy of Nature, many interpreters claim that for Hegel there is no difference in kind between sensing episodes occurring in humans and those occurring in non-rational animals. These readers therefore take Hegelian 'sensations' (and sometimes 'soul') to be something that belongs to or 'is available to animals' (deVries 2013: 54; see also deVries 1988: 54) and constitutes the 'higher form of awareness attained by non-human animals' (Houlgate 2006: 243), thus claiming that 'the thinking animal has sensation, just like all animals' (Gobsch 2017: 143, my translation). In this sense, they attribute to Hegel what we have called a 'low-line' theory of animal cognition.

\section{Difficulties of the additive approach}

Unfortunately, this approach to sensation has both textual and argumentative problems, which makes it highly difficult to uphold and calls for a radical shift in perspective. 


\section{Hegel's Later Theory of Cognition}

First, Hegel does not find sensation, in the form described above, to be a substantive part of cognition, and he often critically addresses its role in various other accounts of the mind. He explicitly maintains that the 'transient', blind, and nonrepresentational episodes he considers are not able to play any role at all in the representation of an object; they are only 'an entirely empty form of subjective affection' (LA: 32-33).

Moreover, isolating sensations from other activities produces a set of further problems. One is the epistemological conundrum presented by the justificatory role of the non-conceptual Given in knowledge claims. This problem is most explicitly formulated by Hegel in his later texts (indeed more explicitly in these texts than in the 1807 Phenomenology where commentators usually locate it). Over the course of his analysis, Hegel develops a distinctly epistemological argument, saying that sensations qua non-conceptual states have no epistemic role to play in substantiating knowledge claims. Sensation 'has no criterion in itself' (LPS: 113), Hegel maintains, and therefore cannot provide any justification for perceptual judgment. Hegel therefore claims that 'it is completely unacceptable to rely on one's own sensations. Whoever does this, leaves the domain of reasons, of thought, $[\ldots]$ and retreats back into his own subjectivity' (PSS: \$400Z) ${ }^{25}$ Given this characterization, sensations for Hegel are at best epistemically inert.

Another issue arises from the role of sensation in the genesis of representations with genuine objective import. The 'additive' theory strongly emphasizes the performance of various mental capacities upon non-conceptual content, such that Hegel would seem to conceive of perceptual experience as 'something that spirit constructs $[\ldots]$ the result of the activity of spirit', as deVries has maintained (deVries 1988: 68, fn.15, my emphasis).

This emphasis on an 'activity' that 'constructs', however, brings Hegel's thought quite close to the set of views that he himself critically labelled 'subjective idealism' because they conceive of 'objectivity' as emerging out of activity. Indeed, it commits Hegel to an account of intentional perceptual content originating from the idea that-in McDowell's words- intellectual activity can somehow make experiences of an objective world out of items that are in themselves less than that' (McDowell 2002: 203).

Not only is this view difficult to defend from the charges of subjective idealism, but Hegel also explicitly rejects it, accusing it from the beginning of his career of giving rise to an idealism that 'leaves no room for the object' (GW 6: 292). This difficulty cannot be overcome, as scholars such as Stephen Houlgate suggest, by arguing that all 'spiritual' activities exercised on a given non-conceptual sensation are carried out in just one act of perception. Though Hegel sometimes appears to move in this direction, the idea of a 'unifying perceptual instant', in which all the steps synthesizing the given are performed together the instant a sensation is received, does nothing to alter the 'constructed' nature of the resulting intentional 


\section{Luca Corti}

content of perception. ${ }^{26}$ This interpretive move thus does not resolve the issue of subjective idealism.

Moreover, the 'additive' reading faces a further exegetical problem in the fact that Hegel, as many interpreters have noted, treats the same activities twice or three times over the course of his argument. ${ }^{27}$ At first this problem of 'repetitions' seems only an overly fastidious exegetical question, but repetition is in fact an essential feature of Hegel's argument — one to which he repeatedly draws his readers' attention. The question of repetition is especially interesting for our purposes, because it applies to 'sensations' as well as to other elements appearing at early stages of Hegel's argument ('feeling', for instance, is discussed three times). Repetition eventually also involves Hegel's notion of the soul, since Hegel treats the 'soul' in two different contexts: first in the Philosopby of Nature and then in the Philosophy of Spirit. If the 'soul' is an autonomous layer already described in a particular section of the text, why would he discuss it twice? This question reflects what Bernard Bourgeois calls the problem of the "the two souls. ${ }^{28}$ In both textual and conceptual terms, accounts that make sense of it are more cogent than those that do not. ${ }^{29}$

\section{Abandoning the additive model: the 'transformative' interpretation}

The problems just highlighted are not knock-out evidence against 'additive' readings. Nonetheless, they justify attempts to look at Hegel from an alternative angle, which might open up new possibilities for interpretation and enable us to resolve many if not all of these issues.

In fact, Hegel himself not only rejects the main assumption of the additive approach — namely the 'separability' thesis—but he also considers such a rejection fundamental to his account of cognition. In his methodological remarks on the Philosophy of Subjective Spirit, he is quite clear on this point: he attacks all approaches to activities of the mind that are based on Trennung and which assume the 'division [Zersplitterung] of spirit into different capacities represented as independent of each other' (PSS: \$379). In numerous other places, Hegel similarly argues against accounts of cognition in which 'whatever is distinguishable in the activity of spirit is defined as an independent determinateness, a procedure which results in spirit's being treated as an ossified and mechanical agglomeration' (PSS: \$445A). One of the reasons for this rejection is that it cannot account for the 'unity' of the cognizing subject. ${ }^{30}$ Any position that commits Hegel to a strong 'separability' of faculties therefore seems not only vulnerable to Hegel's attack but also to ignore Hegel's own intentions.

Moving away from the separability thesis produces a relevant shift in our understanding of Hegel's argument, by turning us away from an understanding of his descriptions of single capacities as operating in isolation and towards a 


\section{Hegel's Later Theory of Cognition}

more robust 'transformative' perspective. Already in the Science of Logic, Hegel had contrasted an additive view of cognition with a holistic, transformative conception of Geist 'in which its determinations interpenetrate, in a much more profound sense' (GW: 11:340). In later texts, he also subscribes to the 'transformative' idea that the presence of higher capacities structurally reshapes lower ones in new ways. In the Philosophy of Spirit, he insists that to be understood in its 'concrete' form each cognitive human activity must be considered as embedded in the general cognitive architecture of a fully developed spirituality. This context alters the very nature of such activities in a distinct way, 'so that what is higher already shows itself to be empirically present in a lower more abstract determination' (PSS: \$380).

This view has fundamental consequences for the structure of Hegel's argument as a whole, since it suggests that activities cannot be articulated conceptually in an independent way: rather, they can be properly understood only once the entire structure has been built, i.e., at the end of the argument. This generates what Hegel repeatedly stresses as the 'specific difficulty' (PSS: \$380) of analysing 'spirit' about which he warns readers (in the introduction of each of his Lectures and throughout his exposition).

To overcome the expository obstacles inherent to writing a transformative account, Hegel adopts a particular procedure. As various scholars have noticed, he uses 'anticipation', which takes on a technical meaning in these parts of his system. As Paul Ziche observes, this feature is a 'necessary methodological tool for a presentation of a philosophy of spirit' (Ziche 2001: 180, my translation). Hegel warns his readers about this feature in numerous places with comments that fall along these lines:

When lower stages are under consideration, it becomes necessary, in order to draw attention to them in their empirical existence, to refer to higher stages in which they are present only as forms. In this way we need at times to introduce, by anticipation, a content which presents itself only later in the development. (PSS: §380, my emphasis; cf. PSS: I: 121).

In short, given Hegel's rejection of separability, the initial definition of an activity is necessarily provisional (in Hegel's terminology 'abstract') and partial. In order to see such an activity or cognitive element fully (or in its 'concreteness'), one has to 'anticipate' the capacities that will be described in the following sections. 'Anticipating', however, must not be equated with 'adding' capacities on top of previous ones - in that case an additive version of rationality would still emerge, together with its problems. 'Anticipating' instead implies rethinking the lower capacities as 'informed' by higher ones. Hegel makes use of the Aristotelian notion of 'form' to illuminate this feature of his theory, in which higher faculties permeate lower ones. ${ }^{31}$ 


\section{Luca Corti}

He deploys this device especially for activities presented in the early stages of his argument in the Anthropology, where the vocabulary of 'anticipation' and 'form' is most visible:

In the Anthropology [...] we do not have spirit yet, but rather only immediate determinations [...]; therefore, we can speak of it only in so far as we refer to the concrete; we have to anticipate the spiritual of the human being. [...] In this exposition we only have forms [Formen] —on the contrary, in the natural progression of Nature, we have shapes [Gestaltungen] — and if we want to talk about those forms [Formen] in a concrete manner, we have to anticipate spirit in its full development. (GW:25:1:222, my transl.)

Such an insistence on 'anticipation' is methodologically motivated and, in my view, best interpreted as prompted by Hegel's transformative understanding of Geist. ${ }^{32}$

If we now return to our example of sensing, we can see that Hegel in fact frees us from the necessity of reading 'sensation' as an autonomous content isolated from higher faculties. On the contrary, to grasp sensing in its 'concrete' form Hegel thinks we should see it as operating within (and affected by) a context in which the subject is able to exercise other capacities (such as deploying symbols, using language, and having thoughts). These capacities, in turn, affect the nature of sensation, whose content thus acquires a different 'form' (on this point see Halbig 2002: 93-94). Hegel's rejections of separability confirm this view:

For the understanding, the difficulty consists in getting away from the separation between the faculties of the soul, feeling and thinking spirit, which it has already fabricated for itself, and in realizing that in the human being there is only one reason in feeling, volition and thought. (PSS: \471, transl. modified)

If one takes Hegel seriously in terms of both (a) his explicit rejection of 'separability', as well as (b) his related explicit insistence on the particular anatomy of his argument (i.e. his use of anticipation precisely to avoid separability), then it becomes clear that the shape of any particular cognitive capacity or power can only be understood by embedding elements into his definition that emerge later in the argument.

This type of transformative interpretation points toward a different Hegelian view on the two points I mentioned in the introduction: non-conceptual content and animal cognition. Indeed, what initially was defined as separable nonconceptual content must now be seen as 'permeated' or informed by higher capacities (including thinking). ${ }^{33}$

Standard 'additive' interpretations of the question of animal cognition also must be revised. By claiming that initial accounts of low-level capacities (presented 


\section{Hegel's Later Theory of Cognition}

in the Anthropology) do not represent 'descriptions' of independent layers of our mental anatomy, and by arguing that what is presented as 'soul' must be reconceived over the course of Hegel's argument, the 'transformative' reader ends up with a distinctly human 'soul' (and the components of experience associated with it) that stands apart from the animal case. Transformed by Hegel's account of human higher faculties and the distinctly human form of self-relation, the human 'soul' no longer appears as something fundamentally shared with animals but instead as an activity that is categorially different. ${ }^{34}$

In support of this point, it may be noted that although Hegel certainly states —as we have seen — that animals have souls, this does not necessarily imply that he thinks they have the same kinds of souls possessed by rational human beings. In fact, he famously stresses the inherent difference between the human and the animal 'soul', notably stating that 'human animality is something totally different from mere animality' (VPGe: 35). Hegel emphasizes that the categorial gap between the two forms of cognition extends to single activities: for instance, he points out that rational beings and non-rational beings do not sense in the same way: in the realm of sensibility, 'the soul of the animal distinguishes itself from the spiritual' (PSS: I: 109). Whereas the animal's sensory engagement with the world can be seen as differentially classifying the environment according to instinct or (blind) animal sensation, humans, as rational beings, display more complex capacities that cognitively penetrate their sensory awareness of the environment. ${ }^{35}$ This marks a crucial difference between the two cases. ${ }^{36}$

Yet the question remains as to why Hegel treats 'sensation' in isolation. Is this in itself not proof that it is a separable component of cognition? What kind of general argument is Hegel adopting here?

Although I do not have space to defend my view here-and my points on transformativism stand independent of any reconstruction of Hegel's argument as a whole, which of course would be more controversial —it is worth mentioning a few key aspects of a potential global understanding of his procedure.

In the Philosophy of Subjective Spirit, Hegel presents a developmental argument that consists of progressive exploration of forms of cognition and self-relation that move from the basic (activities that first emerged in the Pbilosophy of Nature) to the more complex, until finally reaching concrete spiritual activities. These general forms of cognition and self-relation mainly fall under the headings of 'soul', 'consciousness', and 'intelligence'. Hegel's advancement from the 'abstract' to the more 'concrete' is driven, at least in part, by insufficiencies inherent to the forms under investigation. The development of his argument therefore bears a kind of logical necessity, with each insufficiency requiring progressive rethinking of the forms of cognition that were previously addressed-all the way up to (and resulting in) Hegel's conception of Geist. This is why Hegel's definition of sensation cannot be said to be complete until we have reached the level of Geist. ${ }^{37}$ 


\section{Luca Corti}

As a consequence, one could say that the apparently isolated account of 'sensation' found in the Anthropology is provisional and that sensation (in general) becomes intelligible only through a fully developed account of buman sensation. This also applies to animal sensation, which can be made sense of only after one has been introduced to an adequate and comprehensive model of rational cognition, which turns out to logically precede the accounts of animal sensation previously presented in the argument. ${ }^{38}$

The fact that many features of sensation are intelligible only in light of their higher, more fully developed spiritual characterizations is confirmed by Hegel, who states that:

All these differences do not yet pertain to the standpoint of sensation itself however, but to a subsequent reflection of the soul in so far as it has determined itself further as I and then spirit,or to our external reflection if we consider the soul directly in accordance with such differences, as sensation. (PSS: I: 127)

This 'transformative' account-and, in particular, its focus on the unity of Geist and use of 'anticipation'-helps explain the structure of Hegel's text and the issue of textual repetition that has puzzled many scholars. The idea that capacities encounter progressive redefinition over the course of Hegel's argument (thanks to their embeddedness in a progressively more complex cognitive structure) accounts for these repetitions. Take 'feeling', for instance: it is first introduced in the Anthropology but gets reframed in the context of more complex forms of cognition in the Phenomenology and Psychology. Hegel explicitly explains this recurrence of the notion of feeling as a progressive redefinition to help grasp the 'truth' of the notion:

Although we have had to speak of feeling on two former occasions, in each case it was in a different relation. We had to consider it first in respect of the soul [...]. At the standpoint of consciousness, mention was made of feeling a second time. There, however, the determinations of feeling were the material of consciousness, separated from the soul and appearing in the shape of an independent object.

Now, in the third and final instance, feeling has the significance of being the initial form assumed by spirit as such, which constitutes the unity and truth of the soul and of consciousness. (PSS: \$446)

The same considerations explain why Hegel offers two accounts of 'sensation' and 'soul'-one in the Philosopby of Nature and one in the Philosophy of Subjective Spiritand why he insists on the differences between these two kinds of souls. While the 'soul' addressed in the Philosophy of Nature might succeed in capturing basic animal 


\section{Hegel's Later Theory of Cognition}

forms of mental activity, the distinctly human soul—including all of its contents (sensations, feelings) and corresponding activities — can only be fully grasped by taking into account considerations provided later in the text, which eventually reshape the notion to account for distinctly buman mindedness. ${ }^{39}$

Recognizing this 'transformative' form of argumentation thus means interpreting Hegel as taking a version of the 'hard-line' thesis on animal cognition and a new stance on the 'naturalness' of the allegedly lower cognitive element called soul. What this stance is can be specified in various ways, which are beyond the scope of this paper. What I hope to have shown, however, is that any such specification requires first taking a position with regard to the assumptions underlying the 'additive' and 'transformative' interpretive models.

\section{Conclusion}

In this paper I have analysed the existing conceptual space for possible interpretations of Hegel's later theory of cognition and suggested new directions for exploration. I have drawn attention to the fact that the interpretive field can be divided into two fundamentally different camps whose dividing fault line is constituted by a basic assumption regarding the 'separability' of the mind's activities.

An 'additive' reading-one that accepts the separability and additivity of the various cognitive capacities addressed by Hegel—is exegetically inclined to understand Hegel's text as a composite account of human cognition's robustly independent powers. Shared by many scholars who have addressed Hegel's later text, this stance enables theorization of Hegelian non-conceptual content (provided by lower-level capacities, such as sensation) and is consistent with a low-line stance on animal cognition.

On the other hand, rejection of the idea of separability opens space for a 'transformative' approach in which the activities introduced by Hegel over the course of the argument, far from constituting autonomous and independent layers of cognition, need to be rethought and co-defined as the unfolding argument progressively reshapes them. From this perspective, the nature of lower mental activities, once embedded in a larger cognitive structure, is affected at least partially by higher capacities. The human soul thus is always already imbued with higher capacities and as such is modified by a distinctly human form of self-relation. This position is compatible with a form of conceptualism. Moreover, it points towards a hard-line theory on animal cognition.

I have argued that, in light of the textual evidence and argumentative problems resulting from the additive model, there are good reasons to uphold a transformative interpretation of Hegel's later views - though this is still a relatively minor position in the scholarly literature-and to maintain that Hegel builds the 


\section{Luca Corti}

structure of his argument in a manner intended to do justice to his transformative insights on Geist. Such a reading appears to resolve many of the difficulties presented by the competing approach.

My analysis was conducted at a level of abstraction required by the level of generality of the assumptions under discussion. With the example of 'sensation', however, I have shown how such assumptions can concretely impact our approach to single views held by Hegel. I would argue that the implications of these assumptions and potential offered by the transformative view can be extended to many (if not all) of the other parts of Hegel's later theory. For this reason, though separability has not been a theme in scholarship on later Hegel, I think any interpretation of Hegel's theory of cognition must confront and take a stance on the transformative/additive distinction. I therefore hope my analysis will encourage a rethinking of Hegel's later thought and help develop our exploration of this work. ${ }^{40}$

\section{Luca Corti \\ University of Padua, Italy \\ luca.corti@unipd.it}

\section{Notes}

${ }^{1}$ There have been just a handful of systematic studies of Hegel's later account of mind as a whole; scholars have mostly isolated views on single issues, such as 'habits', 'madness', or 'drive'. Publications that comprehensively investigate Hegel's later texts in light of concerns related to perception and cognition include deVries (1988), Eley (1990), Stederoth (2001). Literature on single sections of the work will be mentioned in what follows.

${ }^{2}$ See for instance Stern (2013), Herrmann-Sinai and Ziglioli (2016), Khurana (2017), Bykova (2019).

${ }^{3}$ This is notably a point of a dialogue between German Idealism and current theories of cognition. Kant has certainly been the main protagonist, and his ideas are still furiously debated. For an overview of the controversy on non-conceptualism, see Heidemann (2013) and Schulting (2016). For the problem of the difference between human and animal cognition, see Foster (2010).

${ }^{4}$ See most notably McDowell (1994, 2003, 2009), Brandom (1994, 2009, 2019); for an overview cf. Redding (2007) and Corti (2018). The definition of Hegel as 'super-conceptualist' comes from Hanna (2013).

5 The paradigmatic example of this opposition is the exchange between Stephen Houlgate (2006, 2018) and John McDowell (2008, 2018), in which the former shows that Hegel's later theory has room for non-conceptual content and for some basic episodes shared by humans and animals. 


\section{Hegel's Later Theory of Cognition}

Other scholars, such as deVries (1988) and McCumber (2014) uphold a non-conceptualist view on Hegel that is essentially different from the conceptualist one (cf. below).

${ }^{6}$ The argument that I will put forth here, however, differs in important ways from those previously used to present Hegel as a transformativist. Despite the explicitly Aristotelian inspiration underlying transformative accounts, my argument will not hinge upon any previous commitment to Hegel's Aristotelianism, such as we find for instance in Haase (2013). I moreover will not make substantial reference to Hegel's understanding of the notion of 'life' (Haase 2013, Khurana 2017). In general, I think that one of the distinctive features - perhaps strengths_ of my focus on Hegel's treatment of separability is that it provides arguments for a transformative reading without subscribing to other, more controversial commitments regarding 'life' or 'nature'. This does not mean, as my analysis will show, that my views cannot be compatible with such interpretations. Another distinctive aspect of my approach is that it foregrounds texts that have not yet been investigated in this debate (especially Hegel's Lectures on the Philosophy of Spirit, which-with a few exceptions-are almost absent from the conversation). I will refer to these texts in my analysis and will also note how they complicate the evidence provided by well-reasoned and explicitly 'antitransformative' accounts such as the one advanced by Gobsch (2017). From a general point of view, my account is compatible with the particular kind of Hegelian Aristotelianism proposed by Kern (2020), from whom, as I will show, I draw some insights for my analysis of sensations.

${ }^{7}$ To put it in Boyle's terms: 'We rational animals perceive and desire in the same sense in which any animal perceives and desires; the power that differentiates our minds is something separate and additional' (2016: 2).

${ }^{8}$ For example, he cites Gareth Evans (1982) and Paul Velleman (2000) as proponents of the additive model, while John McDowell figures as a champion of the 'transformative' point of view. Other examples could be found, and the two models have also been used to interpret other thinkers - most notably Kant (Conant 2017) and Nietzsche (Conant 2014). Herder and Aristotle are also inspirational figures for the transformative account.

${ }^{9}$ I follow Boyle's strategy here in making no detailed distinction among different ways of defining the mind's basic structure in terms of 'powers', 'capacities', or 'states'.

${ }^{10}$ An additive theorist, Boyle claims, supposes 'that our animal powers can exist independently of our rational powers, but not conversely: rational powers are taken to be powers precisely to 'step back' from, 'monitor', and 'intervene in' the operations of our animal powers' (Boyle 2016: 16).

11 This is the first way Hegel describes the subject matter of the Anthropology; it appears in some notes from 1811. This definition of 'anthropology' is far from our current understanding of the notion. I will not dwell here on its historical context. For an overview of the various meanings of 'anthropology' at the time, cf. Gaukroger (2016), and Zammito (2002).

${ }^{12}$ Hegel himself attached great value to the Anthropology. He held six series of his Lectures on The Philosophy of Spirit (cf. GW: 25:1-2). In most of them, the Anthropology-far from being a secondary or irrelevant section-occupies the greatest space, sometimes almost the entire lecture. Hegel 


\section{Luca Corti}

also continuously enriched this section of his system. For a discussion, Bauer (2016), and Jaeschke (2010: 347).

13 Abbreviations used:

$E L=$ Hegel, Encyclopedia of the Philosophical Sciences in Basic Outline Part I: Science of Logic, ed. and trans. K. Brinkmann and D. O. Dahlstrom (Cambridge: Cambridge University Press, 2003). EN = Hegel, Hegel's Philosophy of Nature, ed. and trans. M. J. Petry (London and New York: George Allan and Unwin, 1970).

$G W=$ Hegel, Gesammelte Werke, ed. Rheinisch-Westphälischen Akademie der Wissenschaften

(Hamburg: Meiner, 1968).

LA $=$ Hegel, Aesthetics: Lectures on Fine Art, trans. T. M. Knox (Oxford: Clarendon Press, 1975). LPS = Hegel, Lectures on the Philosophy of Spirit (1827-8), trans. R. R. Williams (Oxford: Oxford

University Press, 2007).

PSS = Hegel, Hegel's Philosophy of Subjective Spirit: Being $\iint$ S 377-482 of Part Three of The Encyclopaedia of

Philosophical Sciences (1830) with Zusätze and Including Two Fragments; 'A Fragment on the Philosophy

of Spirit (1822/5)' and 'The Phenomenology of Spirit (Summer Term, 1825)', trans. M. J. Petry

(Dordrecht: D. Reidel Publishing, 1979).

$V P G e=$ Hegel, Vorlesungen über die Philosophie der Weltgeschichte, Berlin 1822/23. Nachschriften von

Karl Gustav Julius von Griesheim, Heinrich Gustav Hotho und Friedrich Carl Hermann Victor von

Kebler, ed. K. Brehmer, K.-H. Ilting and H. N. Seelmann (Hamburg: Meiner, 1996).

$W=$ Fichte, Gesamtausgabe der Bayerischen Akademie der Wissenschaften, ed. R. Lauth (Stuttgart-Bad

Cannstatt: Frommann, 1964).

${ }^{14}$ On the contrary, 'the content of internal sensation comes from spirit: right, religion, and love are within spirit' (GW: 25:2:666). With 'internal sensation', Hegel seems to address episodes that we would call 'psychosomatic'. Today they would be studied by the theory of emotions or moral psychology. In the newly published Lectures, Hegel provides as an example 'blushing from shame' and 'turning pale out of fear' (GW: 25:2:669). The distinction between internal and external sensation has a long history which does not need to be addressed here.

${ }^{15}$ For an overview of these features, cf. Corti (2018).

${ }^{16}$ See for instance the formulation 'sensing in general is the individual spirit living in healthy partnership with its corporeity' (PSS: \401A, translation modified).

17 This is a feature Hegel attributed to sensation from his Jena period onwards. See (GW: 6: 294). ${ }^{18}$ Sometimes Hegel says that sensations are 'transient' (PSS: \$402), but he seems aware that this characterization is incorrect strictly speaking-for being transient already suggests a temporal determination.

${ }^{19}$ Michael Wolff describes Hegel as attempting to define a 'content that is neither propositional content (sensing that...) nor an intentional attitude (sensing something, for instance something warm or rigid)' (1991: 48).

20 This becomes most evident in looking at Hegel's treatment of 'madness', where he explicitly states that he is not arguing that 'madness' is a necessary step in the ontological (or phylogenetic) development of spirit and stresses that his argument is different in kind from ontological or phylogenetic accounts. Wolff has exhaustively shown that Hegel does not present us with the 


\section{Hegel's Later Theory of Cognition}

idea that 'the development of spirit is some sort of natural consequence of a bodily or mental development (phylogenetic or ontogenetic) of man' (1991: 169, my translation). Stanley Rosen makes the same point in more explicit terms: 'Hegel is not a child psychologist or a genetic linguist' (Rosen 2014: 248).

${ }^{21}$ Hegel commonly uses expressions like verarbeiten, verknüpfen, assimilieren; for this metaphor, see McCumber (2014).

22 'First we speak of intuition [Anschaunng], then of representation [Vorstellung], insofar as it is directed to intuition; then we speak of the imagination [Einbildungskraft] as it is directed to the representing activity [...] Next we speak of memory [Gedächtnis], where this is directed to representation of images. What is present in representation is transformed by memory [...]' (LPS: 202-3).

23 John McCumber, for instance, has interpreted this aspect of Hegel's theory of cognition as a progressive 'inwardization' of content: 'We also change what we sense-just as animals change what they eat' (McCumber 2014: 85). Following this line of interpretation, Houlgate has advanced a compelling account of such modification. For Hegel, he claims, 'the sensations of brown, round and hard are given to us, but there being an independent object-for example, a tree-over there is not given. The content we receive in sensation must thus be set over there in thought in order for us to be conscious that what we see and feel is a "tree"" (Houlgate 2006: 244). He also says that 'all that is given to consciousness are sensations. The object-character of the things we see and the causal connections between them are not given but are thought or "posited" by consciousness itself' (2006: 246).

${ }^{24}$ See also Winfield (2007), for instance, whose treatment of psyche as preceding intelligence seems to posit the existence of separable layers of the mind. He describes the mind's activity as 'starting from sensation of its immediate givenness, distinguishing this from mind's own intuiting by paying attention and apprehending the intuited object as something in space and time' (2007: 61-62). He also states that 'intuitions become representations when the mind recollects them'; then the image (Bild) is 'the form intuition takes upon becoming produced and reproduced by mind' (Winfield 2010: 20). The same view, applied to Hegel's Psychology, can be found in Surber (2013).

${ }^{25}$ He offers the same argument in his Lectures: 'When I speak of something objective or about general principles, then that is something universal that is there for everyone. Reasons, principles are also held in common, but this is not a dimension of sensation; rather, the latter means that I am there according to my immediate singularity' (LPS: 155).

${ }^{26}$ Hegel seems to suggest a 'unifying perceptual instant' in which all operations occur at the same time in (PSS: \410Z). He does so by exploiting the notion of babit, writing that 'seeing is the concrete habit, which immediately unifies the diverse determinations of sensation, consciousness, intuition, understanding etc. into a single simple act'. If one takes this as Hegel's position, one needs to work carefully to avoid attributing Hegel an empiricist position (with a Humean flavour) that makes 'habit' responsible for unifying impressions. It is possible, however, to read this section differently, as I will show, making Hegel a critic of this kind of position. 


\section{Luca Corti}

27 On this point, cf. Ziche (2001: 175-76) and Ikäheimo (2000: 31).

28 This is the title of an insightful and understudied essay by Bourgeois (1994).

${ }^{29}$ In his strong defence of an anti-transformative reading of Hegel, Gobsch (2017: 143) sees such repetitions in the Philosophy of Nature and Philosophy of Spirit as evidence that Hegel is talking about the very same thing when addressing human and animal souls ('for this reason, for each determination of the logical form of human soul in the Anthropology, one can find an identical observation in the 'Animal Organism' section - the last part of the Philosophy of Nature-regarding the form of non-thinking animals' (Gobsch 2017: 143, my translation). Aside from the fact that there is no one-to-one correspondence between the two texts, Gobsch does not offer a clear account of why Hegel would treat the same issue twice (or even three times). Why double his account of the soul (and its activities)? Why repeat topics within the Philosophy of Subjective Spirit? In my view, the transformative interpreter is better equipped to answer these questions and to explain the numerous repetitions across the Philosophy of Nature and Philosophy of Spirit as well as within the Philosophy of Subjective Spirit as part of a process of progressive redefinition — or transformation-of the notion of the soul (cf. below).

${ }^{30}$ Many passages show that Hegel is aware of what has come to be known as the 'unity problem': an additive approach to the spirit's activities, Hegel says, 'involves treating spirit as nothing but an aggregation, and considering their [the activities'] relationship as an external and contingent relation' (PSS: $\$ 445 \mathrm{~A}$; the same point is made at LPS: 203). The target of Hegel's attacks is mainly 'empirical psychology', but the empirical psychologist shares the same basic assumption as the 'additive' theorist (cf. Ziche 2001). I cannot fully reconstruct Hegel's argument against empirical psychology here, for more details cf. Corti (forthcoming).

${ }^{31}$ Hegel himself, in his Lectures on the History of Philosophy, praises Aristotle for not having conceived of the relations among the three kinds of souls as additive. Rather than splitting the human soul into three different parts or levels, Aristotle imbues the rational soul with the functions of the other souls (Ferrarin 2001: 249-50; Bourgeois 1994).

${ }^{32}$ Hegel's emphasis on 'anticipation' ( $\left.G W: 25: 1: 63,85,108,220,272,277\right)$ is directly connected to his attempt to conceive of interrelated spiritual activities. As stated above, it is precisely because robust transformative interdependence is a constitutive feature of Geist that Hegel has to refer to anticipation in his account of the latter. For this reason, Hegel maintains that 'when we speak of states in the sphere of Anthropology, we thus have to anticipate' (GW: 25:1:272). Speaking of the soul, 'we always anticipate a step [Stufe]; for us the step is already there, and only in the following it is for soul. This is the whole difference, but it is of great importance' (GW: 25:1:108). In his 1825 Lectures, Hegel again states that 'consciousness here is an anticipation $[. .$.$] we haven't seen this concrete yet, that is the concrete spiritual [gebiltede Geistige],$ in order to speak of it, it has to be anticipated' (GW: 25:1:277). Such interdependence and anticipation make the argument in the Philosophy of Spirit structurally different from the one in the Philosophy of Nature.

${ }^{33}$ This is not to say that for Hegel there is no difference between thinking and sensing, but rather that sensations do entail conceptual content. A similar account of sensation, according 


\section{Hegel's Later Theory of Cognition}

to Paul Redding, can be found in Fichte. According to Redding 'Fichte declares that sensation never appears within consciousness as such as an "isolated presentation", but always in some conceptualized form, as posited “intuition”, or, we would say, perception' (Redding 1999: 97).

34 On this point, see Bourgeois (1994), Brinkmann (1998) and Pinkard (2012: 45): 'The human animal $[. .$.$] practically establishes a new type of self-relation that constitutes consciousness of an$ object and not merely an animal awareness of it'.

35 As Hegel states: 'The animal follows its sensations [Empfindungen], its instinct. Its life contains the measure of what is good and bad for it' (GW: 25:2:651). This, Hegel states, does not apply to humans, whose relation to their environment cannot be described as merely differentially or dispositionally driven by instinct.

36 The same applies to human 'desire': the form of object-relation or intentionality that Hegel calls 'desire' appears to be intrinsically different from the animal case (Pinkard 2012).

${ }^{37}$ For a reading of Hegel's argument along these lines and the idea that the sections of the Anthropology are provisional, cf. Pippin (2005: 202): 'these anthropological elements are understood as initial, very limited successes'. Gabriel (2019) also argues that the views presented at the beginning of Hegel's argument are provisional, but he upholds the radical and more controversial thesis that the notions introduced in the Anthropology are not redefined but rather utterly rejected.

38 My view here is consistent with a central insight of Kern's account of Hegelian Aristotelianism (2020), namely the claim that 'the idea of minded life, Hegel argues, is logically prior to the idea of animal life', and therefore 'none of the concepts that we employ to characterize animal life and its life process $[\ldots]$ can be understood apart from the meaning that these concepts have in an articulation of the idea of minded life' (Kern 2020: 49). In this sense, one could argue that the same kind of view also holds for the numerous forms of self-relation that Hegel explores in the Anthropology. Such forms (such as self-feeling) are intelligible only in light of the full-blown form of self-relation attained in the section titled 'Spirit'; these earlier forms are only partial instantiations.

39 This feature can also explain another anomalous textual element: the fact that Hegel's Philosophy of Spirit contains a sub-section called 'Spirit'. If spirit is the topic of the whole section, why insert a specific sub-section devoted to it? Had Hegel not been discussing it from the beginning of the text? For the transformative interpreter, the reason why Hegel explicitly discusses 'spirit' only at this point is that is only at this point in the argument that we can conceptualize Geist in its concreteness.

40 This project has received funding from the European Union's Horizon 2020 research and innovation programme under the Marie Skłodowska-Curie grant agreement No 845937. 


\section{Luca Corti}

\section{Bibliography}

Bauer, C. J. (2016), 'Editorischer Nachricht', in C. Bauer (ed.), Vorlesungen über die Philosophie des subjektiven Geistes, Vol. III, Anhang. Hamburg: Meiner.

Berthold-Bond, D. (1995), Hegel's Theory of Madness. New York: SUNY Press.

Bourgeois, B. (1994), 'Les deux âmes: de la nature à l'esprit', in J. L. Vieillard-Baron (ed.), De saint Thomas à Hegel. Paris: Presses universitaires de France.

Boyle, M. (2005), Kant and the Significance of Self-consciousness, Dissertation defended on August 30, 2005 at the University of Pittsburgh.

Boyle, M. (2016), 'Additive theories of rationality: A Critique', European Journal of Philosophy 24:2: 1-29.

Brandom, R. (1994), Making It Explicit: Reasoning, Representing, and Discursive Commitment. Cambridge MA: Harvard University Press.

Brandom, R. (2009), Reason in Philosophy: Animating Ideas. Cambridge MA: Harvard University Press.

Brandom, R. (2019), A Spirit of Trust. Cambridge MA: Harvard University Press. Brinkmann, K. (1998), 'The Natural and the Supernatural in Human Nature: Hegel on the Soul', in R. S. Cohen and A. I. Tauber (eds.), Pbilosophies of Nature: The Human Dimension. Dordrecht: Kluwer.

Bykova, M. F. (ed.) (2019), Hegel's Pbilosophy of Spirit: A Critical Guide. Cambridge: Cambridge University Press.

Christensen, D. E. (1968), 'The Theory of Mental Derangement and the Role and Function of Subjectivity in Hegel', The Personalist 49: 433-52.

Conant, J. (2014), Friedrich Nietssche: Perfektionismus und Perspektivismus. Konstanz: Konstanz University Press.

Conant, J. (2017), 'Kant's Critique of the Layer-Cake Conception of Human Mindedness in the B Deduction', in J. O'Shea (ed.), Kant's Critique of Pure Reason: A Critical Guide. Cambridge: Cambridge University Press.

Corti, L. (2018), 'Sense and Sensations. On Hegel's Later Account of Perceptual Experience', in F. Sanguinetti and A. J. Abath (eds.), McDowell and Hegel: Perceptual Experience, Thought and Action. Cham, Switzerland: Springer.

Corti, L. (2018), 'Senses and Sensations: on Hegel's Later Picture of Perceptual Experience', in Hegel and McDowell: Perceptual Experience, Thought and Action, A.J. Abath and F. Sanguinetti (eds.). NY: Springer.

Corti, L. (forthcoming), 'The Two Souls: On The Difference Between Human and Animal Cognition in Hegel's Philosophy of Subjective Spirit and Philosophy of Nature', in J. Wretzel (ed.), The Enduring Relevance of Hegel's Encyclopedia-System. New York and London: Routledge.

deVries, W. A. (1988), Hegel's Theory of Mental Activity: An Introduction to Theoretical Spirit. New York: Cornell University Press. 


\section{Hegel's Later Theory of Cognition}

deVries, W. A. (2013), 'Subjective Spirit: Soul, Consciousness, Intelligence and Will', in A. de Laurentiis, and J. Edwards (eds.), The Bloomsbury Companion to Hegel. London: Bloomsbury.

Eley, L. (ed.) (1990), Hegels Theorie des subjektiven Geistes in der 'Ensylklopädie der philosophischen Wissenschaften im Grundrisse'. Stuttgart: Frommann-Holzboog. Evans, G. (1982), The Varieties of Reference. Oxford: Oxford University Press. Ferrarin, A. (2001), Hegel and Aristotle. Cambridge: Cambridge University Press. Foster, M. (2010). After Herder, Philosophy of Language in the German Tradition. Oxford: Oxford University Press.

Gabriel, M. (2019), 'Hegel's Account of Perceptual Experience in His Philosophy of Subjective Spirit', in M. F. Bykova (ed.), Hegel's Philosophy of Spirit: A Critical Guide. Cambridge: Cambridge University Press.

Gaukroger, S. (2016), The Natural and the Human. Science and the Shaping of Modernity, 1739-1841. Oxford: Oxford University Press.

Gobsch, W. (2017), 'Der Mensch als Widerspruch und absolutes Wissen', in A. Kern and C. Kietzmann (eds.), Selbstbewusstes Leben. Berlin: Suhrkamp.

Haase, M. (2013), 'Life and Mind', in T. Khurana (ed.), The Freedom of Life: Hegelian Perspectives. Berlin: August.

Halbig, C. (2002), Objektives Denken. Erkenntnistheorie und Pbilosophy of Mind in Hegels System. Stuttgart-Bad Cannstatt: Frommann-Holzboog.

Hanna, R. (2013), 'Kant, Hegel, and the Fate of Non-Conceptual Content', Hegel Bulletin 34:1: 1-32.

Heidemann, D. (ed.) (2013), Kant and Non-Conceptual Content. New York: Routledge. Herrmann-Sinai, S. and Ziglioli, L. (eds.) (2016), Hegel's Philosophical Psychology. London and New York: Routledge.

Houlgate, S. (2006), 'Thought and Experience in Hegel and McDowell', European Journal of Philosopby 14:2: 242-61.

Houlgate, S. (2018), 'Hegel, McDowell, and Perceptual Experience: A Response to McDowell', in S. Herrmann-Sinai and L. Ziglioli (eds.), Hegel's Philosophical Psychology. London and New York: Routledge.

Ikäheimo, H. (2000), Self-consciousness and Intersubjectivity: A Study on Hegel's Encyclopedia Philosophy of Subjective Spirit (1830). Jyväskylä: University of Jyväskylä Publications in Philosophy.

Jaeschke, W. (2010), Hegel-Handbuch, Leben-Werk-Schule. Stuttgart-Weimar: Metzler. Kern, A. (2020), 'Life and Mind: Varieties of Neo-Aristotelianism: Naive, Sophisticated, Hegelian', Hegel Bulletin 41:1: 40-60.

Kern, A. and Kietzmann, C. (eds.) (2017), Selbstbewusstes Leben - Texte zu einer transformativen Theorie der menschlichen Subjektivität. Berlin: Suhrkamp.

Khurana, T. (2017), Das Leben der Freiheit Form und Wirklichkeit der Autonomie. Frankfurt: Suhrkamp. 


\section{Luca Corti}

McCumber, J. (2014), Understanding Hegel's Mature Critique of Kant. Stanford: Stanford University Press.

McDowell, J. (1994), Mind and World. Cambridge, MA: Harvard University Press. McDowell, J. (2002), 'Responses', in N. Smith (ed.), Reading McDowell: On Mind and World. London: Routledge.

McDowell, J. (2003), 'Hegel and the Myth of the Given', in W. Welsch and K. Vieweg (eds.), Das Interesse des Denkens. Hegel aus heutiger Sicht. München: Wilhelm Fink.

McDowell, J. (2008), 'Reponses', in J. Lindgaard (ed.), John McDowell: Experience, Norm and Nature. Oxford: Blackwell.

McDowell, J. (2009), Having the World in View: Essays on Kant, Hegel, and Sellars. Cambridge MA: Harvard University Press.

McDowell, J. (2018), 'Response to Stephen Houlgate', in F. Sanguinetti and A. J. Abath (eds.), McDowell and Hegel: Perceptual Experience, Thought and Action. Cham, Switzerland: Springer.

Mills, J. (2000), 'Hegel on the Unconscious Soul,' Science et Esprit, 52:3: 321-40.

Mills, J. (2002), The Unconscious Abyss: Hegel's Anticipation of Psychoanalysis. Albany: SUNY Press.

Pinkard, T. (2012), Hegel's Naturalism: Mind, Nature, and the Final Ends of Life. Oxford: Oxford University Press.

Pippin, R. (2005), The Persistence of Subjectivity: On the Kantian Aftermath. Cambridge: Cambridge University Press.

Redding, P. (1999), The Logic of Affect. Ithaca and London: Cornell University Press. Redding, P. (2007), Analytic Philosophy and the Return of Hegelian Thought. Cambridge: Cambridge University Press.

Rosen, S. (2014), The Idea of Hegel's Science of Logic. Chicago: University of Chicago Press.

Schulting, D. (2016) (ed.), Kantian Non-conceptualism. New York: Palgrave.

Severino, G. (1983), Inconscio e malattia mentale in Hegel. Genova: Il Melangolo.

Stederoth, D. (2001), Hegels Philosophie des subjektiven Geistes. Ein komparatorischer Kommentar. Berlin: Akademie Verlag.

Stern, D. (ed.) (2013), Essays on Hegel's Philosophy of Subjective Spirit. New York: SUNY Press.

Surber, J. P. O. (2013), 'Hegel's Linguistic Thought in the Philosophy of Subjective Spirit: Between Kant and the 'Metacritics', in D. Stern (ed.), Essays on Hegel's Philosophy of Subjective Spirit. New York: SUNY Press.

Velleman, J. D. (2000), The Possibility of Practical Reason. Oxford: Oxford University Press.

Winfield, R. (2007), 'From Representation to Thought: Reflections on Hegel's Determination of Intelligence', The Owl of Minerva 39(1-2): 55-86. 


\section{Hegel's Later Theory of Cognition}

Winfield, R. (2010), Hegel and Mind. Rethinking Philosophical Psychology. New York: Palgrave.

Wolff, M. (1991), Das Körper-Seele-Problem: Kommentar zu Hegel, Enayyklopädie (1830), \389. Frankfurt: Klostermann.

Zammito, J. H. (2002), Kant, Herder and the Birth of Anthropology. Chicago: University of Chicago Press.

Ziche, P. (2001), 'Psychologie und Anthropologie bei Hegel', in O. Breidbach and D. von Engelhardt (eds.), Hegel und die Lebenswissenschaften. Berlin: Verlag für Wissenschaft und Bildung. 